\title{
The Soviet legacy and Russian federalism, 1991-93
}

\section{Russian federalism and the Soviet legacy}

According to the 1977 Constitution, 'the Union of Soviet Socialist Republics' was a 'unified, federal, multinational state formed on the principle of socialist federalism'. The federation, which was established according to the dual principles of ethnicity and territory, encompassed fifteen ethnically defined union republics, twenty autonomous republics, eight autonomous oblasts, ten autonomous okrugs, and 159 territorially based regions.

But if we adopt the definition of a federation given by Watts in chapter 1 , then clearly the USSR was not an authentic federation. For whilst the Constitution proclaimed the republics' rights of sovereignty (article 76), and secession (article 72), the right to enter into treaties with foreign powers (article 80), and local control over economic developments (article 77), such rights were heavily qualified in practice, by the provisions of other articles, which made a mockery of the republic's sovereign powers. ${ }^{1}$ And, in any case, whilst the state was supposedly based on federal principles, the party, which declared itself to be 'the leading and guiding force in society', was a unitary body. Moreover, party and state bodies operated under the principle of 'democratic centralism', whereby each administrative level was subordinate to the level above it, and centralised control from Moscow.

In 1989 Gorbachev publicly admitted that the republics' rights of sovereignty were largely formal in nature, 'Up to now', he noted, 'our state has existed as a centralized and unitary state and none of us has yet the experience of living in a federation'. ${ }^{2}$

This is not to say that the federal subjects in the USSR were totally powerless and subservient to the central authorities or that nationalist demands had been quelled when Gorbachev took over the reins of power in 1985. For paradoxically, the very policies which the communists had used to placate nationalism ended up giving it succour. As Bialer notes, 
the concept and reality of Soviet federalism contained a dangerous dualism: 'On the one hand it granted to formed nations cultural autonomy, territorial integrity, and symbols of statehood; on the other hand it insisted on the supremacy of the central state and government and strove for a state of affairs where national separateness and ethnic identity would ultimately wither away'.3

The USSR's adoption of an 'ethno-territorial' form of federalism was originally designed as a temporary measure, adopted to entice the nonRussian nationalities to join the union. But as Gleason notes, such a principle entailed a recognition of the 'national statehood' of the constituent republics. ${ }^{4}$ Under Soviet federalism, 'ethnicity was institutionalised both on the individual and on group levels. On the individual level, nationality was registered on each person's internal passport... At the group level, the ethno-territorial basis of political organization established firm links between national groups, their territories, and their political administrations' ${ }^{5}$

In addition, according to Stalin's formula 'national in form, socialist in content', the nations of the Soviet Union were supposed to develop to the point where all national groups would be equal. But as Zwick notes: 'In its attempt to neutralize tribal, ethnic and religious identifications and replace them with socialist norms, the Soviet regime awakened national feelings among its population, and then, by promising to equalize all nations, made the people acutely aware of the differences that had always existed between Russians and non-Russians'. ${ }^{6}$

Soviet nationality policies even promoted nation building for national communities which had 'not yet achieved ethnic awakening in the prerevolutionary period'. ${ }^{7}$ And far from withering away, the administrative organs of the republics gradually developed a sense of 'proprietary bureaucratic self-interest' ${ }^{\prime}$

\section{Federalism and nationalism under Gorbachev}

Gorbachev's policies of perestroika, glasnost and democratisation opened up the nationalities and federal question to nationwide debate. Gorbachev's dilemma was how to simultaneously reform the Soviet economy and polity, whilst maintaining the unity of the communist party and the state. In the end, Gorbachev failed on all counts. His acknowledgement of the legitimate demands of the republics for greater economic and political autonomy, and his proposals for a revived 'Union of Soviet Sovereign States' came far too late to save the Union. The rise of Russian nationalism coupled with the collapse of the communist party over the period 1990 to 1991 finally propelled the Soviet Union into the abyss.

Gorbachev's reluctant acceptance of the need for an asymmetrical form of Soviet federalism, mixing confederal relations for some (the three Baltic 
republics, Georgia, Moldova and Armenia) with varying degrees of federal relations with the others, stemmed from a genuine belief on his part in the economic benefits to be gained in preserving the Union. Gorbachev repeatedly stressed the interdependent nature of the Soviet economic system and the fact that the republics 'rely on a division of labour in a highly institutionalised, integrated national economic complex; depend on the central authorities for resource allocations, investments, subsidies and grants-in-aid; and enjoy the diplomatic, economic and military advantages that accrue to a superpower. To cut such ties would mean to dissect a living body'. ${ }^{9}$

But economic decentralisation soon led to calls for political decentralisation. And once the CPSU began to fragment along political and ethnic lines there was nothing left to hold the Union together. Elections for republican parliaments in 1990 inflicted heavy defeats on the communist party candidates in the majority of the republics. In April 1990 Yeltsin gained the chair of the Russian (RSFSR) parliament and in June Russia made its historic declaration of sovereignty, whereby it proclaimed: 'full power of the RSFSR in decisions on all questions of state and public life ... the priority of the RSFSR's Constitution and Laws on the entire territory of the RSFSR; the exclusive right of the people to ownership, use and disposal of the national riches of Russia, and the right of free exit from the USSR'. ${ }^{10}$

The Russian government under Yeltsin's leadership now began to champion the rights of other republics. And between 'June and October [1990], Uzbekistan, Moldova, Ukraine, Belorussia, Turkmenistan, Tajikistan and Kazakhstan declared their sovereignty, while Armenia ... took the further step of declaring its independence'. ${ }^{11}$ Yeltsin also entered into negotiations with these 'sovereign republics', and even signed a number of bilateral treaties with them.

Over the autumn-winter period 1990-91 Gorbachev seemed to abandon the 'democratic' camp. It appeared as if he was determined to save the Union at all costs. But after the failure of Soviet OMON troops to set up 'national salvation fronts' in the Baltics in January 1991, Gorbachev tried another tack, seeking instead to gain approval for his Union Treaty through a nationwide referendum. But the results of the referendum, held in March 1991, was inconclusive, and at best represented a pyrrhic victory for Gorbachev, for although 76.4 per cent of those participating supported 'a renewed federation of equal sovereign republics', six of the fifteen republics refused to participate in the ballot (Estonia, Latvia, Lithuania, Armenia, Georgia and Moldova). ${ }^{12}$ As Lapidus notes:

Faced with the choice between the hard liner's pressure to maintain the Soviet Union through force by imposing a new Union Treaty from above and the democratic demands to concede real sovereignty to the republics, 
Gorbachev struck a deal with Yeltsin and the leaders of those nine republics which participated in the March 1991 referendum. ${ }^{13}$

According to the provisions of this so-called $9+1$ agreement, signed on April 23, 1991, the three Baltic republics, Armenia, Georgia, and Moldova were to be allowed to secede from the USSR and a new fourth version of the Union Treaty was to be concluded in the summer. As John Miller notes, 'Implicit in this was recognition by the Union administration of the sovereignty of the Union-Republics; and that the federation inaugurated by the Union Treaty should be a very weak one in which the Centre would retain only a minimum of power'. ${ }^{14}$

It was the plans to sign the Union Treaty on August 20, 1991, which sparked off the attempted coup. The failure of the coup, in turn, accelerated the demise of the USSR, leading to its total collapse by December.

As we noted above, Russia's declaration of Sovereignty in June 1990 was a major catalyst in the collapse of the USSR. But the RSFSR was itself a quasi-federation comprising sixteen ethnically defined autonomous soviet socialist republics (ASSRs), ten national okrugs (districts) and five autonomous oblasts. And seven other such 'autonomies' were trapped inside a further four Soviet republics. ${ }^{15}$ If Russia could declare its sovereignty, then why should the autonomous republics within Russia not follow suit? After all, some of these ASSRs (e.g., Tatar and Bashkir) were actually larger and more populous than some of the Soviet republics (e.g., Estonia, Latvia, Moldova). Whilst Gorbachev's polices had led to the rise of nationalism in the USSR, Yeltsin's policies were in danger of leading to a similar rise of national sentiment in the RSFSR. As, Aleksandr Tsipko warned:

the stronger the striving of the RSFSR to free itself from the centre, the stronger will be the desire of the autonomous formations to free themselves from Yeltsin. And in their own way they are right. The relations of Russia to the autonomies is constructed on the same principle as that of the Union to the RSFSR. ${ }^{16}$

Over the period 1990-91 the ASSRs became embroiled in the wider struggle between Yeltsin and Gorbachev. In an attempt to weaken Russia's role in the negotiations over the Union Treaty, Gorbachev began to espouse the need to raise the status of the autonomies. In the All-Union Law, 'On the Delimitation of Powers between the USSR and the Subjects of the Federation' of April 26, 1990, the autonomous republics, were described as 'subjects of the federation' thus recognising their right to equal representation with the union republics, in the negotiations over the Union treaty. ${ }^{17}$ In reply, Yeltsin, on a nationwide tour of the Russian Federation in August 1990, urged the ASSRs to 'take as much sovereignty as they could swallow'. Furthermore, he proclaimed, 'if this meant full independence from Russia 'your decision will be final'. ${ }^{18}$ And it was not long 
before the ASSRs took Yeltsin at his word, and unilaterally declared their sovereignty. On August 30, 1990, Tatarstan declared itself the sixteenth republic of the USSR, ${ }^{19}$ and by the end of the year almost every other autonomy had likewise declared its independence from its host union republic (see table 2.1).

On December 15, 1990 the Russian Congress of People's Deputies adopted a series of amendments to the RSFSR Constitution, which raised the status of its sixteen ASSRs to constituent republics of the Russian Federation. In addition, in July 1991, the Russian Supreme Soviet adopted a number of decrees, which, 'elevated the status of four of Russia's autonomous oblasts, Adygeya, Gornii Altai, Karachaevo-Cherkessiya and Khakasiya (with the exception of the Jewish autonomous oblast in Siberia), to constituent republics of the federation' ${ }^{20}$ This brought the total number of ethnic republics within Russia to twenty.

Table 2.1 Dates of declarations of sovereignty

\begin{tabular}{ll}
\hline Republic & Date of declaration of sovereignty \\
\hline $\begin{array}{l}\text { North Osetiya- } \\
\text { Alaniya }\end{array}$ & July 20, 1990 \\
Kareliya & August 9, 1990 \\
Khakassiya & August 15, 1990 \\
Komi & August 29, 1990 \\
Tatarstan & August 30, 1990 \\
Udmurtiya & September 20,1990 \\
Sakha (Yakutiya) & September 27, 1990 \\
Buryatiya & October 8, 1990 \\
Bashkortostan & October 11, 1990 \\
Kalmykiya & October 18, 1990 \\
Marii El & October 22, 1990 \\
Chuvashiya & October 24, 1990 \\
Gorno-Altai & October 25, 1990 \\
Tuva & November 1, 1990 \\
Karachai- & November 17, 1990 \\
Cherkessiya & \\
Checheno- & November 27, 1990 \\
Ingushetiya & \\
Mordova & December 8, 1990 \\
Kabardino-Balkariya & January 31, 1991 \\
Dagestan & May 15, 1991 \\
Adygeya & July 2, 1991 \\
\hline
\end{tabular}

Source: Jeff Kahn, 'The parade of sovereignties: establishing the vocabulary of the new Russian federalism', Post-Soviet Affairs, 16:1 (2000), 62. 
After the collapse of the USSR, the number of republics within Russia increased to twenty-one, when in the summer of 1992 the ChechenoIngush Republic was separated into Chechen and Ingush republics. Thus, the Soviet Union's hybrid ethno-territorial principal of federalism was bequeathed to Russia.

\section{The foundations of Russia's constitutional institutions}

The founding constitutional arrangements of any regime must surely be considered as one of the most important factors determining the future trajectory of the state. The tragedy for Russian federalism and Russian democracy is the fact that: (1) The collapse of communism in the USSR was at best an incomplete 'revolution' which largely witnessed the replacement of one set of Soviet leaders headed by Gorbachev, by another set of Russian elites under Yeltsin. Whilst it could be argued that a circulation of elites within the Russian state did slowly take place over the period 1991-93, only a partial circulation occurred in the regions and republics where 'nomenklatura continuity' has been the norm rather than the exception. ${ }^{21}$ (2) A new alliance of regional political and economic elites soon took hold as Russia embarked on a massive privatisation programme in 1992-93. These groups were the first to be given access to the rich pickings of the regional 'privatisation troughs'. Both of these groups had a vested interest in demanding economic and political sovereignty for their territories, and it was not long before they took advantage of the vacuum of power in the centre to proclaim their rights of control and/or ownership over the vast natural resources and wealth of their regions. Thus, for example, in 1991 almost 80 per cent of industrial output in Tatarstan was produced by enterprises under the command of central economic bodies but by 1993, 70 per cent of these enterprises had been transferred to Tatarstan's own jurisdiction. ${ }^{22}$

Tragically, for Russia, the founding political and economic institutions in the regions, were forged not by newly elected democrats but rather by authoritarian leaders who emerged out of the old Soviet nomenklatura. Russia's post-communist elites, particularly in the ethnic republics, soon turned to nationalism and separatist demands, rather than democracy, to legitimate their rule. Wielding the sword of 'sovereignty' local elites were able to capture control over the major political and economic institutions in the localities. Thus, in a short space of time many of Russia's republics were headed by authoritarian regimes of one sort or another.

Over the period October 1991-October 1993 the federal authorities in Moscow were engaged in a 'civil war' which pitted the Russian presidency and government against the Russian parliament. For two years the central powers in Moscow were paralysed by this all-encompassing battle. The conflict took many forms but in essence it centred around the 
struggle over the ratification of a new constitution. The parliamentarians fought for a parliamentary constitution which would give them sweeping powers and relegate the president to a ceremonial figurehead. The president on the other hand sought to create a presidential constitution with a weak parliament and a powerful executive presidency. Numerous presidential and parliamentary drafts of the constitution were drawn up during this time, but it was only after the dissolution of parliament in September 1993 that Yeltsin was able to push ahead with his presidential constitution which was eventually ratified in December 1993 (see below).

During this period of weak central power the republics became especially vociferous in their demands for national autonomy. In the absence of a new federal Constitution many of the ethnic republics unilaterally granted themselves a whole series of rights and privileges. The republics and regions were also wooed by representatives of both the parliament and president, who promised the regions ever greater degrees of autonomy. Making the best of the political impasse in Moscow, regional elites scored a great victory when Yeltsin signed the 1992 Federal Treaty. The Treaty granted both the republics and regions greater powers over their own affairs, and in particular gave the ethnic republics considerable control over their natural resources; the rights of secession, citizenship and sovereignty.

Thus, the founding constitutional arrangements and concomitant political institutions, which would determine the future path of Russian federalism, were forged during a period of weak and divided federal authority (1991-93) and crucially, before the ratification of the Russian Constitution of December 1993.

\section{The Federal Treaty}

The Federal Treaty of March 31, 1992 created an 'asymmetrical federation' with the rights granted to the ethnic republics far outweighing those given to the territorially based regions. ${ }^{23}$ For some scholars the treaty was a necessary compromise to save the Union whilst others argue that it fundamentally weakened federalism in Russia by constitutionally sanctioning an asymmetrical federal state with three types of legal subject, each possessing different rights and powers; national-state formations (sovereign republics); administrative-territorial formations (krais, oblasts, and the cities of Mocow and St Petersburg); and national-territorial formations (the autonomous oblast and autonomous okrugs). The Federal Treaty also recognised three distinct areas of competence; federal, joint federalregional and regional.

The republics were recognized as sovereign states with rights of national self-determination territorial integrity, and by implication the 
right to secede from the Union. They were awarded citizenship rights and ownership of their land and natural resources. The republics were also granted their own constitutions and powers to elect their own executive heads. In addition they were free to sign bilateral treaties with foreign countries and to engage in foreign economic relations at their own discretion without the need even to consult the centre. ${ }^{24}$ The regions were given no such rights of ownership, nor were they allowed such freedom to engage in international relations. And instead of constitutions, the regions were only permitted to draw up local charters, and their top executives were to be appointed from above.

Bashkortostan and Sakha signed the Federal Treaty only after they were granted special concessions, including special dispensions with regard to their contributions to the federal budget. Bashkortostan was also granted the additional right to create its own independent legal system. ${ }^{25}$ Two republics, Tatarstan and Chechnya, refused to sign the treaty. Tatarstan later ratified its own republican constitution in November 1992 which (in article 61) affirmed that the republic was, 'a sovereign state and a subject of international law, associated with the Russian Federation'. Only Chechnya went so far as to declare its outright independence, a move which eventually led to the invasion of Russian troops into the republic in 1994, and again in 1999.

But it was not long before this two-class federal system came under attack from the regions, which demanded parity with the ethnic republics. As Lapidus and Walker note: 'Why should the inhabitants of Kareliya, where the Karelians make up only 10 per cent of the population and Russians almost 75 per cent, enjoy special economic privileges simply because they live in a region arbitrarily designated an autonomous area'? ${ }^{26}$

In protest, regional authorities also began to withhold their tax revenues refusing to give them up to the federal authorities. As Sakwa observes, 'In 1993, for example, Moscow collected only forty per cent of the tax revenues due to it from the regions and republics, and over two dozen refused to pay the centre their federal tax obligations' ${ }^{27}$ And in August 1993 the heads of a number of regions demanded that the privileges granted to the republics in the Federal Treaty be rescinded.

Indeed, a number of regions were so incensed by their secondclass positions within the federation that they unilaterally elevated their status to that of republics. Thus, for example, in a referendum held in April 1993, 84 per cent of the population of Sverdlovsk Oblast supported the creation of the Urals Republic. ${ }^{28}$ And it was not long before further regions followed suit. Thus, for example, regions in European Russia created the Pomor Republic centred in Arkhangelsk, the Central Russian Republic, made up of eleven regions with its capital in Orel, and the Leningrad Republic in St Petersburg. A Southern Urals republic was 
formed in Chelyabinsk, and a Siberian republic in Irkutsk. And in the Far East, the Maritime Republic was created in Vladivostok. ${ }^{29}$ Other regions whilst not going so far as to declare themselves republics, unilaterally elevated their constitutional status. Thus, for example, Voronezh Oblast declared that the region was henceforth, an 'independent participant in international and foreign-economic relations'. Furthermore it continued, 'Federal bodies of state power of the Russian Federation may not promulgate legal acts that fall within the jurisdiction of the regional bodies of power'. ${ }^{30}$

Many of these issues were discussed at a special constitutional conference which Yeltsin eventually was persuaded to convene in the summer of 1993. Ostensibly the conference was devoted to the task of making peace with the parliament and the drawing up a draft constitution which would bring together elements of the rival parliamentary and presidential constitutions. However, it was clear from the start that this was not an open conference with delegates democratically elected from below, rather it was a top-down organisation whose membership was chosen from above. The proceedings were dominated by Yeltsin, who had no intention of compromising on his 'presidential version' of the constitution.

Nonetheless, during the conference Tatarstan took the lead in pushing for more autonomy for the ethnic republics insisting that Russian federalism should be 'treaty based' rather than 'constitutional'. In particular, the republics demanded:

1 the right of all of Russia's people's to self-determination,

2 recognition of themselves as sovereign states possessing full state (legislative, executive and judicial) power on their territory, except for powers that were voluntarily transferred to the jurisdiction of the Russian Federation,

3 the right to enter into direct relations with other states and to exchange diplomatic and consular missions,

4 acknowledgement that federal principles of legislation would enter into force on their territories only after they were ratified by local bodies of power, and

5 recognition of their right to secede from the Russian Federation without any restraint. ${ }^{31}$

The regions in return continued to press for their status to be elevated to that of the republics and for the special privileges granted to the republics to be abolished. As Vyachislav Novikov (chair of the Krasnoyarsk Krai Soviet (assembly) and head of the Association of Regional Soviets) noted, the proposed definition of republics as sovereign states was 'a bomb under Russia's future' and but the first step on the path to the creation of 'a Russian confederation'. ${ }^{32}$ 
But the president, buoyed up by the surprise show of support given to his administration in the April 1993 referendum, was in no mood for compromise with either the parliament or the ethnic republics. Indeed, the president now sought to reverse the powers which he had relinquished to the regions in the Federal Treaty. Realising which way the wind was blowing, a number of the republics walked out of the conference. But this only made it easier for Yeltsin to call for full economic and political equality to be granted to all subjects of the federation and the abolition of special rights for the ethnic subects. ${ }^{33}$

The work of the constitutional conference continued to operate after Yeltsin's violent dissolution of the Russian Parliament in October 1993. But it was no longer needed by the president. As Sergei Pakhomenko noted: 'The Parliament is no more - and the conference is now like the unfortunate chicken whose chopped-off head is clutched in the fist of the cook while its body continues to run around the yard in confusion for a time' ${ }^{34}$

At the meeting of the Public Chamber (one of the smaller bodies set up at the conference), on October 23, it was recommended that all references to the sovereignty of the republics should be deleted from the draft constitution as should the articles which guaranteed republican citizenship. Finally, it was recommended that the Federal Treaty was to be removed from the constitution. Yeltsin's draft constitution (the fourth version) was finally published on November 10, 1993 and as discussed in chapter 3, the constitution was finally ratified on December $17,1993 .^{35}$

\section{Notes}

1 See, in particular, articles 73 and 134.

2 'Draft nationalities policy of the party under present conditions', adopted by the CPSU Central Committee Plenum, September 20, 1989, quoted in S. Kux, 'Soviet Federalism', Problems of Communism (March-April, 1990), 2.

3 S. Bialer, Stalin's Successors: Leadership, Stability and Change in the Soviet Union (Cambridge: Cambridge University Press: 1980), pp. 210-11.

4 G. Gleason, Federalism and Nationalism: The Struggle for Republican Rights in the USSR (Boulder; San Francisco; Oxford: Westview Press, 1990), p. 3.

5 P. Goldman, G. Lapidus and V. Zaslavasky, 'Introduction: Soviet federalism its origins, evolution and demise', in G. Lapidus, V. Zaslavsky and P. Goldman (eds), From Union to Commonwealth: Nationalism and Separatism in the Soviet Republics (Cambridge: Cambridge University Press, 1992), p. 2.

6 P. R. Zwick, 'Soviet nationality policy: social, economic, and political aspects', in G. Smith (ed.), Public Policy and Administration in the Soviet Union (New York: Praeger, 1980), p. 149.

7 Lapidus, Goldman and Zaslavsky, 'Introduction', p. 2.

8 Gleason, Federalism and Nationalism, p. 3.

9 Kux, 'Soviet federalism', pp. 6-7. 
10 See articles 5 and 7 of the Soviet Constitution.

11 A. Brown, The Gorbachev Factor (Oxford; New York: Oxford University Press, 1997), p. 287.

12 Ibid., p. 256.

13 Goldman, Lapidus, Zaslavsky, 'Introduction', p. 15.

14 J. Miller, Mikhail Gorbachev and the End of Soviet Power, (New York: St Martin's Press, 1993), p. 175.

15 There were two ASSRs in Georgia and one each, in Azerbaijan and Uzbekistan. There was also one autonomous region in the republics of Azerbaijan, Georgia and Tadjikistan.

16 J. B. Dunlop, The Rise of Russia and the Fall of the Soviet Empire (Princeton University Press, 1993), p. 64.

17 A. Sheehy, 'Russia's republics: a threat to its territorial integrity?', Radio Free Europe/Radio Liberty Research Report, 2:20 (14 May 1993), 36.

18 Dunlop, The Rise of Russia, p. 62.

19 M. Filippov and O. Shevtsov, 'Asymmetric bilateral bargaining in the new Russian Federation: a path dependence explanation', Communist and PostCommunist Studies, 32 (1999), 70.

$20 \mathrm{~J}$. T. Ishiyama, 'The Russian proto-parties and the national republics', Communist and Post-Communist Studies, 29: 4 (1996), 397.

21 See D. Lane and C. Ross, From Communism to Capitalism: Ruling Elites from Gorbachev to Yeltsin, (New York: St Martin's Press, 1999).

22 A. Zverev, 'Qualified sovereignty: the Tatarstan model for resolving conflicting loyalities', in M. Waller, B. Coppieters and A. Malashenko (eds), Conflicting Loyalties and the State in Post-Soviet Russia and Eurasia (London: Frank Cass, 1998), p. 137.

23 There were actually three federal treaties, with separate agreements for the republics, the autonomies and the regions. The treaties were ratified by the Sixth Session of the Russian Congress of People's Deputies on 10 April 1992.

24 A. F. Fedorov, Rossiiskii Federalizm: Istoricheskii Opyt i Sovremennost' (Moscow: Nauchnya Kniga, 1997), p. 97.

25 Ibid.

26 G. W. Lapidus and E. W. Walker, 'Nationalism, regionalism, and federalism: center-periphery relations in post-communist Russia', in G. W. Lapidus (ed.), The New Russia: Troubled Transformation, (Boulder, Colorado: Westview Press, 1995), p. 96.

27 Richard Sakwa, Russian Politics and Society (London and New York: Routledge, 2nd edn, 1996), p. 188.

28 On October 23, 1993 Sverdlovsk Oblast adopted the Constitution of the Urals Republic. However, President Yeltsin on November 9, 1993 suspended the activities of the Soviet and declared the formation of the republic unconstitutional. See V. Shlapentokh, R. Levita and M. Loiberg, From Submission to Rebellion: The Provinces Versus the Centre in Russia (Boulder, Colorado: Westview Press, 1998), pp. 109-10.

29 Ibid., p. 109.

30 The declaration by the oblast Soviet was made on September 3, 1993.

31 Current Digest of the Post Soviet Press (hereafter, CDPSP), 45:23 (1993), p. 12, and also Shlapentokh, Levita and Loiberg, From Submission to Rebellion, p. 106. 
32 A. Tarasov, 'A bomb under Russia's future', Izvestiya (June 24, 1993), pp. 1-2, translated in CDPSP, 45:25 (1993), p. 4.

33 Fedorov, Rossiiskii Federalizm, p. 103.

34 S. Parkhomenko, Sevodnya (October 26, 1993), p. 1, translated in the CDPSP, 45:43 (1993), p. 7.

35 L. Shevtsova, Yeltsin's Russia: Myths and Realities (Washington, DC: Carnegie, 1999), p. 93. 